\title{
Dietary Wheat Gluten Alleviates the Elevation of Serum Transaminase Activities in D-Galactosamine-Injected Rats
}

\author{
Atsushi Manabe, Chew Chuang Cheng, Yukari Egashira, \\ Takeo OHTA, and Hiroo SANADA* \\ Division of Bioproduction Science, Faculty of Horticulture, \\ Chiba University, Matsudo 271, Japan
}

(Received September 29, 1995)

\begin{abstract}
Summary The effects of dietary protein on the elevation of activities of serum aspartate aminotransferase (AST) and alanine aminotransferase (ALT) in D-galactosamine-injected rats were investigated. The rats fed with experimental diets containing test protein sources for 2 weeks were injected with D-galactosamine $\left(0.8 \mathrm{~g} \cdot \mathrm{kg}^{-1}\right.$ body weight $)$. The activities of AST and ALT in serum were assayed after $20 \mathrm{~h}$. According to the results, these enzyme activities in the rats fed $40 \%$ casein diet were higher than those of 5,10 , or $20 \%$ casein groups. In the $40 \%$ gluten group, these enzyme activities were lower than in the $40 \%$ casein group. This difference was not considered to be caused by the deficit of L-lysine and L-threonine in gluten. The extent of the reduction of UTP and UDPglucose in liver by D-galactosamine was almost the same in the $40 \%$ gluten and $40 \%$ casein groups. These results suggest that levels and quality of dietary protein affect the susceptibility of animals to the hepatotoxin D-galactosamine and dietary gluten was found to alleviate the elevation of serum transaminases in rats by the drug.
\end{abstract}

Key Words gluten, protein, D-galactosamine, transaminase, hepatitis, rats

In the treatment of hepatitis, the effects of protein nutrition and parenteral alimentation with special amino acid mixture are taken into account. However, we could find few reports which describe the effects of dietary protein on the pathogenesis of hepatitis. Although hepatitis has been shown to develop in response to many different causes such as virus, alcohol and various kinds of chemicals, Dgalactosamine-induced hepatitis has been well studied as a model of hepatitis which resembles viral hepatitis in histological features (1). The injury of hepatocytes by D-galactosamine was suggested to be developed through suppression of mRNA (2, $3)$ or glycoprotein synthesis $(4,5)$ in association with the reduction of uridine triphosphate in the cells $(2-4)$. There are some reports which describe the

\footnotetext{
* To whom correspondence should be addressed.
} 
prevention of D-galactosamine-induced hepatitis not only by the administration of uridine or orotic acid (3) but also by tryptophan + methionine or nicotinamide + methionine (6). However, the effect of dietary protein on the effect of $\mathrm{D}$ galactosamine has not been investigated. Further, some investigators suggested the involvement of endotoxin derived from enteric bacteria in the induction of hepatitis by D-galactosamine $(7,8)$. Although the influence of dietary protein on the metabolism of uridine derivatives or the invasion of endotoxin into blood is unknown, we describe in the present report the effect of dietary protein on the pathogenesis of hepatitis induced by D-galactosamine in rats using serum transaminases as indices.

\section{MATERIALS AND METHODS}

Materials. D-Galactosamine hydrochloride was purchased from Sigma Chemicals (St. Louis, USA). All amino acids and wheat gluten were obtained from Wako Pure Chemicals (Tokyo) and transaminase assay kit, Iatrozyme TA-Lq from Iatron Laboratories Inc (Tokyo). Soybean protein isolate was the kind gift from Fuji Oil Company (Osaka, Japan). Casein was provided by Oriental Yeast Industry (Tokyo). Pentobarbital sodium solution (Nembutal sodium) was obtained from Dynabot (Osaka, Japan). Nucleoside diphosphate kinase and UDPG dehydrogenase were purchased from Sigma Chemicals. Aqueous solution of D-galactosamine used for injection was prepared by adjusting its $\mathrm{pH}$ to 7.0 and concentration to $300 \mathrm{~g} \cdot$ liter $^{-1}$ followed by the sterilization by membrane filtration before use.

Animals and diets. Male Wistar rats (4 or 5 weeks of age, the latter being used only in experiment 2) were obtained from Clea Japan (Tokyo) and were housed in an air-conditioned room at $22 \pm 1{ }^{\circ} \mathrm{C}$ with a 12 -h light-dark cycle. They were assigned to groups ( 8 rats in each group except experiment 5) after feeding with a commercial diet (CE-1, Clea Japan) for 7 days. Then the rats had free access to their experimental diets throughout the 15-day experiment. The experimental diets were as follows: $5,10,20$ or $40 \%$ casein diet $(5 \mathrm{C}, 10 \mathrm{C}, 20 \mathrm{C}$ or $40 \mathrm{C}$, respectively) for experiment 1; 20\% casein, 40\% casein, $40 \%$ gluten or $40 \%$ soybean protein diet $(20 \mathrm{C}, 40 \mathrm{C}, 40 \mathrm{G}$ or $40 \mathrm{~S}$, respectively) for experiment $2 ; 20 \%$ casein, 40\% casein, 40\% gluten, 40\% gluten supplemented with L-lysine and L-threonine needed for normal growth or $40 \%$ casein diet supplemented with L-glutamine to make the concentration of total glutamic acid (glutamic acid + glutamine) similar to that of the $40 \%$ gluten diet $(20 \mathrm{C}, 40 \mathrm{C}, 40 \mathrm{G}, 40 \mathrm{GLT}$ or $40 \mathrm{CGl}$, respectively) for experiment 3; 20\% casein, 30\% casein, 30\% gluten supplemented with L-lysine and L-threonine, 30\% amino acid mixture which mimicked the amino acid composition of wheat gluten, or 30\% casein diet supplemented with glutamine of which the dietary content was equal to that of the $30 \%$ gluten diet $\left(20 \mathrm{C}^{\prime}, 30 \mathrm{C}, 30 \mathrm{GLT}, 30 \mathrm{AA}\right.$ or $30 \mathrm{CGln}$, respectively) for experiment 4; and $40 \%$ casein or $40 \%$ gluten diet for experiment 5 . The composition of these 
Table 1. Composition of experimental diets for experiments 1, 2, 3 and 5.

\begin{tabular}{|c|c|c|c|c|c|c|c|c|}
\hline Ingredients & $5 \mathrm{C}$ & $10 \mathrm{C}$ & $20 \mathrm{C}$ & $40 \mathrm{C}$ & $40 \mathrm{G}$ & $40 \mathrm{~S}$ & $40 \mathrm{GLT}$ & $40 \mathrm{CGl}$ \\
\hline & \multicolumn{8}{|c|}{$\left(\mathrm{g} \cdot \mathrm{kg}^{-1}\right.$ diet $)$} \\
\hline Casein & 50 & 100 & 200 & 400 & - & - & - & 361.2 \\
\hline Wheat gluten & - & - & - & - & 400 & - & 400 & - \\
\hline Soy protein & - & - & - & - & - & 400 & - & - \\
\hline L-Lysine $\cdot \mathrm{HCl}$ & - & - & - & - & - & - & 22.8 & - \\
\hline L-Threonine & - & - & - & - & - & - & 6.8 & - \\
\hline L-Glutamine & - & - & - & - & - & - & - & 38.8 \\
\hline Cornstarch & 550 & 500 & 400 & 200 & 200 & 200 & 170.4 & 200 \\
\hline Sucrose & 253 & 253 & 253 & 253 & 253 & 253 & 253 & 253 \\
\hline Corn oil & 50 & 50 & 50 & 50 & 50 & 50 & 50 & 50 \\
\hline Vitamin mix. $^{a}$ & 10 & 10 & 10 & 10 & 10 & 10 & 10 & 10 \\
\hline Mineral mix. ${ }^{a}$ & 35 & 35 & 35 & 35 & 35 & 35 & 35 & 35 \\
\hline Cellulose & 50 & 50 & 50 & 50 & 50 & 50 & 50 & 50 \\
\hline Choline bitartrate & 2 & 2 & 2 & 2 & 2 & 2 & 2 & 2 \\
\hline
\end{tabular}

${ }^{\mathrm{a}}$ Composition of $\operatorname{AIN76}{ }^{\mathrm{TM}}(26)$.

Table 2. Composition of experimental diets for experiment 4.

\begin{tabular}{|c|c|c|c|c|c|}
\hline Ingredients & $20 C^{\prime}$ & $30 \mathrm{C}$ & $30 \mathrm{G}$ & $30 \mathrm{AA}$ & $30 \mathrm{CGl}$ \\
\hline & \multicolumn{5}{|c|}{ Basal diet $\left(\mathrm{g} \cdot \mathrm{kg}^{-1}\right.$ diet $)$} \\
\hline Casein & 200 & 300 & - & - & 213.9 \\
\hline Wheat gluten & - & - & 300 & - & - \\
\hline L-Lysine $\cdot \mathrm{HCl}$ & - & - & 17.1 & 17.1 & - \\
\hline L-Threonine & - & - & 5.1 & 5.1 & - \\
\hline L-Glutamine & - & - & - & - & 86.1 \\
\hline Amino acid mix. ${ }^{a}$ & - & - & - & 300 & - \\
\hline Cornstarch & 400 & 300 & 277.8 & 277.8 & 300 \\
\hline Sucrose & 253 & 253 & 253 & 253 & 253 \\
\hline Corn oil & 50 & 50 & 50 & 50 & 50 \\
\hline Vitamin mix. ${ }^{\mathrm{b}}$ & 10 & 10 & 10 & 10 & 10 \\
\hline Mineral mix. ${ }^{b}$ & 35 & 35 & 35 & 35 & 35 \\
\hline Cellulose & 50 & 50 & 50 & 50 & 50 \\
\hline \multirow[t]{2}{*}{ Choline bitartrate } & 2 & 2 & 2 & 2 & 2 \\
\hline & \multicolumn{5}{|c|}{ Supplement $\left(\mathrm{g} \cdot \mathrm{kg}^{-1}\right.$ basal diet $)$} \\
\hline Cellulose acetate phthalate & 10 & 10 & 10 & 10 & 10 \\
\hline
\end{tabular}

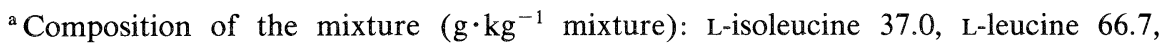
L-lysine $\cdot \mathrm{HCl} 17.3$, methionine 16.1 , L-cystine 19.8 , L-phenylalanine 50.6 , L-tyrosine 30.9, L-threonine 24.7, L-tryptophan 9.7, L-valine 40.8, L-histidine 22.2, L-arginine 33.3, L-alanine 25.9, L-aspartic acid 33.3, L-glutamine 354.4 , glycine 33.3 , and L-proline 140.8, L-serine 43.2.

${ }^{\mathrm{b}}$ Composition of AIN76 ${ }^{\mathrm{TM}}$ (26). 
experimental diets are shown in Tables 1 and 2. The diets for experiment 4 contained cellulose acetate phthalate which was reported to reduce the osmotic pressure of ingested amino acids in the gastrointestinal tract (9). On day 14, they were injected with D-galactosamine $\left(0.8 \mathrm{~g} \cdot \mathrm{kg}^{-1}\right.$ body weight $)$ intraperitoneally, and then $20 \mathrm{~h}$ later blood was drawn by heart puncture under anesthesia. In experiment 5 , blood was collected at 0,1 , and $8 \mathrm{~h}$ after galactosamine injection. Diets were withheld for $4 \mathrm{~h}$ before and after galactosamine injection. The care and treatment of the rats were carried out according to the guidelines prescribed at our institution and the NIH Guide for the care and use of laboratory animals (10).

Analysis. The activities of aspartate aminotransferase (EC 2.6.1.1) (AST) and alanine aminotransferase (EC 2.6.1.2) (ALT) in the serum were determined by a clinical enzyme assay kit, Iatrozyme TA-Lq (Iatron Laboratories). The contents of UTP, UDP and UDP-glucose in rat liver were determined by the sequential enzymatic methods (11).

Statistical analysis. The activities of AST and ALT were analyzed by the Kruskal-Wallis test and subsequently by non-parametric Scheffe's multiplecomparison test in addition to Wilcoxon's runk sum test (only for experiment 5) after the removal of abnormal values according to Smirnoff's test (12). Other data were analyzed using ANOVA followed by Duncan's multiple-range test. All analysis was conducted using Yukm Statistical Library (A.S.B Inc, Tokyo).

\section{RESULTS}

\section{Effects of casein contents in diets}

As shown in Table 3, growth in the 5C and 10C groups was significantly lower than in the $20 \mathrm{C}$ group and the relative liver weight to the eviscerated carcass weight was significantly higher in the $5 \mathrm{C}$ and $10 \mathrm{C}$ groups than in the $20 \mathrm{C}$ group. Although the activities of serum AST and ALT deviated within a wide range in each group, the means of those activities in the $40 \mathrm{C}$ group were significantly higher than in the other 3 groups.

\section{Effects of various kinds of protein sources}

When the rats were fed with the $40 \mathrm{G}$ diet for 15 days, their body weight gain was significantly lower than the other three groups, and their relative liver weight to eviscerated carcass weight was slightly but significantly higher than in the other three groups (Table 4). The activities of serum AST and ALT in the 40C group was significantly higher than in the $20 \mathrm{C}$ group. On the other hand, those enzyme activities in the $40 \mathrm{G}$ group were significantly lower than in the $40 \mathrm{C}$ and $40 \mathrm{~S}$ groups.

Effect of L-lysine, L-threonine and total L-glutamic acid (glutamic acid + glutamine)

As shown in Table 5, the supplementation of L-lysine and L-threonine to the gluten diet resulted in the recovery of the growth of the rats to the same level as in the $40 \mathrm{C}$ group. The relative weight of liver to the eviscerated carcass weight of 
Table 3. Effect of dietary protein levels on body weight gain, feed intake, relative weight of liver to eviscerated carcass weight and serum transaminase activities in galactosamine-treated rats. (Experiment 1)

\begin{tabular}{lcccc}
\hline & $5 \mathrm{C}$ & $10 \mathrm{C}$ & $20 \mathrm{C}$ & $40 \mathrm{C}$ \\
\hline Initial body weight $(\mathrm{g})$ & $93 \pm 1$ & $93 \pm 1$ & $93 \pm 1$ & $93 \pm 1$ \\
Final body weight $(\mathrm{g})$ & $89 \pm 2^{\mathrm{a}}$ & $138 \pm 4^{\mathrm{b}}$ & $197 \pm 3^{\mathrm{c}}$ & $202 \pm 3^{\mathrm{c}}$ \\
Weight gain $(\mathrm{g} / 15 \mathrm{~d})$ & $-5 \pm 1^{\mathrm{a}}$ & $44 \pm 3^{\mathrm{b}}$ & $103 \pm 3^{\mathrm{c}}$ & $109 \pm 2^{\mathrm{c}}$ \\
Feed intake $(\mathrm{g} / 15 \mathrm{~d})$ & $105 \pm 4^{\mathrm{a}}$ & $172 \pm 10^{\mathrm{b}}$ & $246 \pm 5^{\mathrm{c}}$ & $233 \pm 3^{\mathrm{c}}$ \\
Eviscerated carcass weight (g) & $66 \pm 1^{\mathrm{a}}$ & $99 \pm 3^{\mathrm{b}}$ & $148 \pm 3^{\mathrm{c}}$ & $150 \pm 2^{\mathrm{c}}$ \\
Liver weight (g) & $4.1 \pm 0.1^{\mathrm{a}}$ & $6.0 \pm 0.2^{\mathrm{b}}$ & $8.0 \pm 0.1^{\mathrm{c}}$ & $8.5 \pm 0.1^{\mathrm{d}}$ \\
Relative liver weight & $6.2 \pm 0.2^{\mathrm{c}}$ & $6.0 \pm 0.2^{\mathrm{bc}}$ & $5.4 \pm 0.1^{\mathrm{a}}$ & $5.7 \pm 0.1^{\mathrm{ab}}$ \\
$\quad(\mathrm{g} / 100 \mathrm{~g}$ eviscerated carcass weight) & & & & \\
Activity of serum enzyme & & & & \\
$\quad\left(\mu \mathrm{mol} \cdot\right.$ min $^{-1} \cdot$ liter $\left.^{-1}\right)$ & & & & \\
$\quad$ AST & $365 \pm 59^{\mathrm{a}}$ & $430 \pm 68^{\mathrm{ab}}$ & $364 \pm 33^{\mathrm{a}}$ & $780 \pm 109^{\mathrm{b}}$ \\
ALT & $109 \pm 25^{\mathrm{a}}$ & $239 \pm 45^{\mathrm{ab}}$ & $155 \pm 28^{\mathrm{ab}}$ & $483 \pm 115^{\mathrm{b}}$ \\
\hline
\end{tabular}

Values are $\mathbf{M} \pm \mathbf{S E M}$ for 8 rats in each group. Values within each row not sharing a common superscript letter are significantly different $(p<0.05)$ by Duncan's multiplerange test (for all items without activity of serum enzymes) or non-parametric Scheffe's multiple-comparison test (for activity of serum enzymes).

Table 4. Effect of casein, gluten and soybean protein in diets on the body weight gain, feed intake, relative weight of liver to eviscerated carcass weight and serum transaminase activity in galactosamine-treated rats. (Experiment 2)

\begin{tabular}{lcccc}
\hline & $20 \mathrm{C}$ & $40 \mathrm{C}$ & $40 \mathrm{G}$ & $40 \mathrm{~S}$ \\
\hline Initial body weight $(\mathrm{g})$ & $128 \pm 2$ & $128 \pm 1$ & $128 \pm 1$ & $128 \pm 1$ \\
Final body weight $(\mathrm{g})$ & $229 \pm 3^{\mathrm{b}}$ & $230 \pm 4^{\mathrm{b}}$ & $206 \pm 3^{\mathrm{a}}$ & $237 \pm 4^{\mathrm{b}}$ \\
Weight gain $(\mathrm{g} / 15 \mathrm{~d})$ & $101 \pm 3^{\mathrm{b}}$ & $102 \pm 3^{\mathrm{b}}$ & $78 \pm 3^{\mathrm{a}}$ & $109 \pm 4^{\mathrm{b}}$ \\
Feed intake $(\mathrm{g} / 15 \mathrm{~d})$ & $267 \pm 8$ & $260 \pm 7$ & $255 \pm 6$ & $277 \pm 5$ \\
Eviscerated carcass weight $(\mathrm{g})$ & $173 \pm 2^{\mathrm{b}}$ & $172 \pm 3^{\mathrm{b}}$ & $148 \pm 2^{\mathrm{a}}$ & $179 \pm 3^{\mathrm{b}}$ \\
Liver weight $(\mathrm{g})$ & $9.6 \pm 0.2$ & $9.6 \pm 0.2$ & $9.9 \pm 0.2$ & $9.9 \pm 0.2$ \\
Relative liver weight & $4.2 \pm 0.1^{\mathrm{a}}$ & $4.2 \pm 0.05^{\mathrm{a}}$ & $4.8 \pm 0.1^{\mathrm{b}}$ & $4.2 \pm 0.1^{\mathrm{a}}$ \\
$\quad(\mathrm{g} / 100 \mathrm{~g}$ eviscerated carcass weight) & & & & \\
Activity of serum enzyme & & & & \\
$\quad\left(\mu \mathrm{mol} \cdot \mathrm{min}^{-1} \cdot\right.$ liter $\left.^{-1}\right)$ & & & & \\
AST & $916 \pm 197^{\mathrm{ab}}$ & $1567 \pm 235^{\mathrm{b}}$ & $211 \pm 9^{\mathrm{a}}$ & $1173 \pm 232^{\mathrm{b}}$ \\
ALT & $314 \pm 73^{\mathrm{ab}}$ & $689 \pm 124^{\mathrm{b}}$ & $94 \pm 7^{\mathrm{a}}$ & $722 \pm 185^{\mathrm{b}}$ \\
\hline
\end{tabular}

Values are $\mathrm{M} \pm$ SEM for 8 rats in each group. Values within each row not sharing a common superscript letter are significantly different $(p<0.05)$ by Duncan's multiplerange test (for all items without activity of serum enzymes) and non-parametric Scheffe's multiple-comparison test (for activity of serum enzymes).

40GLT group, however, was not affected by these amino acids. The supplementation of L-glutamine to $40 \%$ casein diet to make the content of total glutamic acid (glutamic acid +glutamine) equal to that of the $40 \%$ gluten diet did not affect the 
Table 5. Effect of gluten supplemented with L-lysine and L-threonine, and casein supplemented with glutamine to make the content of total glutamic acid (glutamic acid + glutamine) the same as that of gluten on body weight gain, feed intake, relative weight of liver to eviscerated carcass weight and the activities of serum transaminases in galactosamine-treated rats. (Experiment 3)

\begin{tabular}{lccccc}
\hline & $20 \mathrm{C}$ & $40 \mathrm{C}$ & $40 \mathrm{G}$ & $40 \mathrm{GLT}$ & $40 \mathrm{CGl}$ \\
\hline Initial body weight $(\mathrm{g})$ & $95 \pm 1$ & $95 \pm 1$ & $95 \pm 1$ & $95 \pm 1$ & $95 \pm 2$ \\
Final body weight $(\mathrm{g})$ & $196 \pm 3^{\mathrm{b}}$ & $199 \pm 2^{\mathrm{bc}}$ & $172 \pm 2^{\mathrm{a}}$ & $206 \pm 4^{\mathrm{c}}$ & $199 \pm 2^{\mathrm{bc}}$ \\
Weight gain $(\mathrm{g} / 15 \mathrm{~d})$ & $101 \pm 2^{\mathrm{b}}$ & $104 \pm 2^{\mathrm{b}}$ & $77 \pm 2^{\mathrm{a}}$ & $112 \pm 3^{\mathrm{c}}$ & $104 \pm 1^{\mathrm{b}}$ \\
Feed intake $(\mathrm{g} / 15 \mathrm{~d})$ & $273 \pm 6^{\mathrm{b}}$ & $267 \pm 4^{\mathrm{b}}$ & $242 \pm 6^{\mathrm{a}}$ & $266 \pm 3^{\mathrm{b}}$ & $273 \pm 5^{\mathrm{b}}$ \\
Eviscerated carcass weight $(\mathrm{g})$ & $146 \pm 2^{\mathrm{b}}$ & $147 \pm 2^{\mathrm{b}}$ & $120 \pm 2^{\mathrm{a}}$ & $152 \pm 3^{\mathrm{b}}$ & $147 \pm 1^{\mathrm{b}}$ \\
Liver weight $(\mathrm{g})$ & $8.5 \pm 0.4^{\mathrm{a}}$ & $9.6 \pm 0.5^{\mathrm{ab}}$ & $8.9 \pm 0.3^{\mathrm{a}}$ & $10.6 \pm 0.3^{\mathrm{b}}$ & $9.3 \pm 0.4^{\mathrm{a}}$ \\
Relative liver weight (g/100g & $5.8 \pm 0.3^{\mathrm{a}}$ & $6.5 \pm 0.3^{\mathrm{ab}}$ & $7.4 \pm 0.3^{\mathrm{c}}$ & $7.0 \pm 0.2^{\mathrm{bc}}$ & $6.3 \pm 0.2^{\mathrm{ab}}$ \\
$\quad$ eviscerated carcass weight) & & & & & \\
Activity of serum enzyme & & & & & \\
$\quad\left(\mu \mathrm{mol} \cdot \min ^{-1} \cdot\right.$ liter $\left.^{-1}\right)$ & & & & & \\
$\quad$ AST & $426 \pm 36^{\mathrm{ab} *} 580 \pm 25^{\mathrm{b} *}$ & $157 \pm 20^{\mathrm{a} *}$ & $216 \pm 28^{\mathrm{a}}$ & $590 \pm 28^{\mathrm{b} *}$ \\
ALT & $248 \pm 48^{\mathrm{ab}}$ & $491 \pm 49^{\mathrm{b} *}$ & $95 \pm 15^{\mathrm{a} *}$ & $148 \pm 28^{\mathrm{ab}}$ & $509 \pm 45^{\mathrm{b} *}$ \\
\hline
\end{tabular}

Values are $\mathbf{M} \pm \mathbf{S E M}$ for 8 rats in each group except those with $*$ which are $\mathbf{M} \pm$ SEM for 7 rats. Values within each row not sharing a common superscript letter are significantly different $(p<0.05)$ by Duncan's multiple-range test (for all items without activity of serum enzymes) and non-parametric Scheffe's multiple-comparison test (for activity of serum enzymes).

growth of the animals. The activities of serum AST and ALT in the 40GLT group were slightly higher than in the $40 \mathrm{G}$ group but were not significantly different from the $40 \mathrm{G}$ group. Only the AST activity in the 40GLT group was lower than in the $40 \mathrm{C}$ group. Although the content of total glutamic acid (glutamic acid + glutamine) in the 40CGl diet was almost the same as that of the $40 \mathrm{G}$ diet, the activities of serum AST and ALT in the 40CG1 group were not different from those in the $40 \mathrm{C}$ group, and were significantly higher than in the $40 \mathrm{G}$ group.

\section{Effects of L-glutamine and a mixture of amino acids which simulate gluten composi- tion}

The growth of the rats fed with 30AA, the amino acid composition of which mimicked that of gluten, was significantly lower than in the other four groups (Table 6). The supplementation of L-glutamine to casein diet (30CGln) to make its content similar to that of the $30 \mathrm{G}$ diet did not affect the growth of the rats, but did increase the relative weight of the liver to the eviscerated carcass weight to the same level as the $30 \mathrm{G}$ group. The activities of serum AST and ALT in the 30AA and $30 \mathrm{CG}$ in groups were not significantly different from the $30 \mathrm{G}$ group but only those in the 30AA group were significantly lower than in the $30 \mathrm{C}$ group. 
Table 6. Effect of amino acid mixture with a composition mimicking that of gluten, and casein supplemented with L-glutamine on growth, feed intake, relative weight of liver to eviscerated carcass weight and the activities of serum transaminases in Dgalactosamine-treated rats. (Experiment 4)

\begin{tabular}{lccccc}
\hline & $20 \mathrm{C}^{\prime}$ & $30 \mathrm{C}$ & $30 \mathrm{G}$ & $30 \mathrm{AA}$ & $30 \mathrm{CGln}$ \\
\hline Initial body weight $(\mathrm{g})$ & $108 \pm 1$ & $109 \pm 1$ & $109 \pm 1$ & $109 \pm 1$ & $109 \pm 1$ \\
Final body weight $(\mathrm{g})$ & $212 \pm 3^{\mathrm{b}}$ & $216 \pm 3^{\mathrm{b}}$ & $211 \pm 3^{\mathrm{b}}$ & $192 \pm 2^{\mathrm{a}}$ & $211 \pm 2^{\mathrm{b}}$ \\
Weight gain $(\mathrm{g} / 15 \mathrm{~d})$ & $103 \pm 3^{\mathrm{b}}$ & $108 \pm 2^{\mathrm{b}}$ & $103 \pm 3^{\mathrm{b}}$ & $82 \pm 2^{\mathrm{a}}$ & $102 \pm 2^{\mathrm{b}}$ \\
Feed intake $(\mathrm{g} / 15 \mathrm{~d})$ & $272 \pm 4^{\mathrm{c}}$ & $267 \pm 8^{\mathrm{cb}}$ & $247 \pm 8^{\mathrm{a}}$ & $254 \pm 4^{\mathrm{ab}}$ & $276 \pm 4^{\mathrm{c}}$ \\
Eviscerated carcass weight $(\mathrm{g})$ & $157 \pm 3^{\mathrm{b}}$ & $162 \pm 2^{\mathrm{b}}$ & $156 \pm 3^{\mathrm{b}}$ & $141 \pm 1^{\mathrm{a}}$ & $156 \pm 2^{\mathrm{b}}$ \\
Liver weight (g) & $8.7 \pm 0.2^{\mathrm{b}}$ & $8.9 \pm 0.2^{\mathrm{b}}$ & $9.4 \pm 0.3^{\mathrm{bc}}$ & $7.6 \pm 0.4^{\mathrm{a}}$ & $10.0 \pm 0.5^{\mathrm{c}}$ \\
Relative liver weight (g/100g & $4.1 \pm 0.1^{\mathrm{ab}}$ & $4.1 \pm 0.1^{\mathrm{ab}}$ & $4.5 \pm 0.1^{\mathrm{bc}}$ & $4.0 \pm 0.2^{\mathrm{a}}$ & $4.7 \pm 0.2^{\mathrm{c}}$ \\
$\quad$ eviscerated carcass weight) & & & & & \\
Activity of serum enzyme & & & & & \\
$\quad\left(\mu \mathrm{mol} \cdot \min ^{-1} \cdot\right.$ liter $\left.^{-1}\right)$ & & & & & \\
$\quad$ AST & $521 \pm 23^{\mathrm{ab} *}$ & $703 \pm 19^{\mathrm{b} *}$ & $253 \pm 25^{\mathrm{a} *}$ & $372 \pm 58^{\mathrm{a}}$ & $461 \pm 85^{\mathrm{ab}}$ \\
ALT & $239 \pm 33^{\mathrm{ab}}$ & $485 \pm 39^{\mathrm{b} *}$ & $167 \pm 27^{\mathrm{a}}$ & $188 \pm 35^{\mathrm{ab}}$ & $244 \pm 68^{\mathrm{ab}}$ \\
\hline
\end{tabular}

Values are $\mathrm{M} \pm \mathrm{SEM}$ for 8 rats in each group except those with * which are $\mathrm{M} \pm$ SEM for 7 rats. Values within each row not sharing a common superscript letter are significantly different $(p<0.05)$ by Duncan's multiple-range test (for all items without activity of serum enzymes) and non-parametric Scheffe's multiple-comparison test (for activity of serum enzymes).

\section{Alteration of liver uridine nucleotide}

As shown in Table 7, the activities of AST and ALT were elevated after $8 \mathrm{~h}$ in the $40 \mathrm{G}$ group. These activities at 0 and $1 \mathrm{~h}$ after the injection of galactosamine were not different between the $40 \mathrm{C}$ and $40 \mathrm{G}$ groups. At 8 and $20 \mathrm{~h}$, however, both these enzyme activities in the $40 \mathrm{G}$ group were significantly lower than those in the $40 \mathrm{C}$ group. The contents of UDP-glucose and UTP in the liver in the $40 \mathrm{C}$ and $40 \mathrm{G}$ groups were decreased significantly after $8 \mathrm{~h}$. However, no difference was observed in the concentration of these substances at any time point between the $40 \mathrm{C}$ and $40 \mathrm{G}$ groups.

\section{DISCUSSION}

The present experiments demonstrated that the rats fed with a high protein diet become more susceptible to D-galactosamine than those fed a normal or a low protein diet. Moreover, the susceptibility was found to be affected by the sources of dietary protein and the rats fed with a diet containing wheat gluten was less sensitive to D-galactosamine than those fed with a diet containing the same amount of casein or soybean protein. As shown in Table 3, the plasma activities of AST and ALT before the action of D-galactosamine were very low as compared with those at $20 \mathrm{~h}$ after the drug even in rats fed $40 \%$ casein or gluten diet, and there was no difference between these dietary groups. Moreover, our preliminary experiments 
Table 7. Change of the concentration of UDP, UDP-glucose and UTP in the liver of rats fed with $40 \mathrm{C}$ or $40 \mathrm{G}$ diet after D-galactosamine injection. (Experiment 5)

\begin{tabular}{|c|c|c|c|c|c|}
\hline & \multicolumn{4}{|c|}{ Time after galactosamine injection $(\mathrm{h})$} & \multirow{2}{*}{ Significance } \\
\hline & 0 & 1 & 8 & 20 & \\
\hline \multicolumn{6}{|l|}{$40 \mathrm{C}$ group } \\
\hline & \multicolumn{4}{|c|}{ serum transaminase $\left(\mu \mathrm{mol} \cdot \min ^{-1} \cdot\right.$ liter $\left.^{-1}\right)$} & Kruskal-Wallis \\
\hline AST & $76.4 \pm 18.8^{\mathrm{ab}}$ & $82.4 \pm 10.5^{\mathrm{a}}$ & $401.7 \pm 47.5^{\mathrm{ab}}$ & $524.4 \pm 16.0^{\mathrm{b}}$ & $p<0.05$ \\
\hline ALT & $28.0 \pm 11.1$ & $26.2 \pm 7.7$ & $213.8 \pm 40.3$ & $453.6 \pm 7.4$ & $p<0.05$ \\
\hline & \multicolumn{4}{|c|}{ concentration of uridine derivatives $\left(\mu \mathrm{mol} \cdot \mathrm{g}^{-1}\right.$ liver $)$} & ANOVA \\
\hline UDP & $0.083 \pm 0.014$ & $0.096 \pm 0.010$ & $0.054 \pm 0.023$ & $0.089 \pm 0.007$ & \\
\hline $\begin{array}{l}\text { UDP- } \\
\text { glucose }\end{array}$ & $0.550 \pm 0.049^{\mathrm{b}}$ & $0.501 \pm 0.046^{\mathrm{ab}}$ & $0.393 \pm 0.033^{\mathrm{a}}$ & $0.389 \pm 0.002^{\mathrm{a}}$ & $p<0.05$ \\
\hline UTP & $0.144 \pm 0.015^{\mathrm{b}}$ & $0.115 \pm 0.035^{\mathrm{ab}}$ & $0.053 \pm 0.013^{\mathrm{a}}$ & $0.042 \pm 0.017^{\mathrm{a}}$ & $p<0.05$ \\
\hline \multicolumn{6}{|l|}{$40 G$ group } \\
\hline & \multicolumn{4}{|c|}{ serum transaminase $\left(\mu \mathrm{mol} \cdot \min ^{-1} \cdot \operatorname{liter}^{-1}\right)$} & Kruskal-Wallis \\
\hline AST & $65.0 \pm 14.5$ & $73.0 \pm 6.7$ & $102.4 \pm 27.9^{*}$ & $303.2 \pm 37.0^{*}$ & $p<0.05$ \\
\hline ALT & $25.2 \pm 1.8^{\mathrm{a}}$ & $26.7 \pm 0.6^{\mathrm{ab}}$ & $62.7 \pm 20.9^{\mathrm{ab} *}$ & $176.5 \pm 25.4^{\mathrm{b} *}$ & $p<0.05$ \\
\hline & \multicolumn{4}{|c|}{ contents of uridine derivatives $\left(\mu \mathrm{mol} \cdot \mathrm{g}^{-1}\right.$ liver $)$} & ANOVA \\
\hline UDP & $0.085 \pm 0.013$ & $0.075 \pm 0.019$ & $0.061 \pm 0.013$ & $0.096 \pm 0.025$ & \\
\hline $\begin{array}{l}\text { UDP- } \\
\text { glucose }\end{array}$ & $0.562 \pm 0.031^{b}$ & $0.572 \pm 0.002^{\mathrm{b}}$ & $0.445 \pm 0.041^{\mathrm{a}}$ & $0.422 \pm 0.027^{\mathrm{a}}$ & $p<0.05$ \\
\hline UTP & $0.146 \pm 0.019^{b}$ & $0.137 \pm 0.017^{\mathrm{b}}$ & $0.056 \pm 0.012^{\mathrm{a}}$ & $0.072 \pm 0.011^{\mathrm{a}}$ & $p<0.01$ \\
\hline
\end{tabular}

Values are $\mathbf{M} \pm$ SEM $(n=4)$. Values within each row not sharing a common superscript letter are significantly different $(p<0.05)$ by Duncan's multiple-range test (for all items without activity of serum enzymes) or by non-parametric Scheffe's multiplecomparison test (for serum transaminases). Values with an asterisk are significantly different $(p<0.05)$ from the values in the same category and time in the $40 \mathrm{C}$ group by Wilcoxon's rank sum test (for serum transaminases).

indicated that the activities of hepatic AST and ALT in the rats fed 30\% casein were not different from those fed 30\% gluten (data not shown). These facts suggests that the leakage of these enzyme from D-galactosamine-treated hepatocytes would be different between these dietary groups. Although the reason why the high protein diet resulted in the high sensitivity to galactosamine is not clear, the suppressive effect of gluten on the galactosamine susceptibility was thought to be caused by amino acids. Since the contents of glutamine in the gluten used in the present experiments was estimated to be about $36 \%$ of protein by the methods of Wilcox (13), which was roughly 3 -fold more than that in casein, glutamine but not glutamic acid might be responsible for these effects. However, this explanation was not confirmed. Tryptophan and methionine were reported to reduce the effects of D-galactosamine in rats when these substances were injected simultaneously (6). In the present experiments, however, plasma transaminase activities in the $40 \mathrm{C}$ group after galactosamine injection were not lower than those in the $40 \mathrm{G}$ group, in which the diet contained less tryptophan and methionine than the $40 \mathrm{C}$ diet. Although the 
mechanism by which D-galactosamine induces hepatitis has not been elucidated completely, it was reported that the increase in serum transaminases was preceded by decreases in the contents of UTP and UDP-glucose in the liver after the administration of D-galactosamine and that such changes in serum enzymes was prevented by the administration of uridine in the early phase after the galactosamine injection, according to the recovery of the contents of uridine nucleotides in the liver (2). Therefore, glutamine might be used as the amide donor for the synthesis of uridine nucleotides which would serve to replenish their deficit caused by D-galactosamine. The present results indicate that the contents of UTP, UDP and UDP-glucose in the liver of the $40 \mathrm{G}$ group at $20 \mathrm{~h}$ after the administration of D-galactosamine were slightly higher than those in the $40 \mathrm{C}$ group but the difference was not significant. Thus, the abovementioned hypothesis could not be confirmed. The relative weight of the liver to the eviscerated carcass weight in animals given a gluten- or glutamine-rich diet was always greater than those of the other groups. This phenomenon can be explained by their resistance to the atrophic action of D-galactosamine but also by the swelling of hepatocytes after glutamine incorporation (14). The activities of serum AST and ALT in experiment 2 were comparatively higher than those of the corresponding groups in other experiments. Some slight differences in experimental conditions such as the initial age could be responsible but the reason is unknown.

The injury caused by D-galactosamine injection was reported to be limited to the liver which is the organ where D-galactosamine is primarily metabolized (1), and perturbation of glycoprotein biosynthesis was also shown to be specific to hepatocytes (4). In the investigation using cultured hepatocytes, D-galactosamine in the medium caused decreased UTP and UDPG concentrations in the cells and the reduction was recovered by the addition of uridine (15). In these experiments, however, leakage of intracellular lactate dehydrogenase (LDH), AST and ALT was not acceralated for at least $80 \mathrm{~min}$ after D-galactosamine treatment (15). On the other hand, the leakage of LDH from freshly prepared hepatocytes was not shown to be accelerated till $20 \mathrm{~h}$ after the addition of D-galactosamine (16). Moreover, using $48 \mathrm{~h}$-precultured rat hepatocytes, $4 \mathrm{mM}$ of D-galactosamine in the medium was found not to alter the leakage of intracellular LDH and AST for at least $24 \mathrm{~h}$ after its treatment (17). These results suggest that the leakage of transaminases from hepatocytes into the blood by the injection of D-galactosamine would be caused not only by its direct action on hepatocytes but also by other unknown factors. Since some investigators reported that internal endotoxin was involved in the pathogenesis of hepatitis induced by D-galactosamine $(7,8)$ and that the treatment with D-galactosamine resulted in the remarkable sensitization to endotoxin (18), it is likely that gluten attenuates the action of galactosamine by preventing the invasion of endotoxin in their gut. Glutamine was shown to be used preferentially as a fuel source in enterocytes (19) and to be beneficial for fortification of the mucosal barrier against invasion of endotoxin and microflora $(20,21)$. In our preliminary experiments, however, the concentration of blood endotoxin was 
not lower in the rats fed with a gluten-rich diet compared with a casein-rich diet (data not shown). Because the gut was reported to release L-alanine in conjunction with the consumption of glutamine $(19,22)$, it may be possible that alanine from a portal vein can affect the action of D-galactosamine in the liver. Another plausible explanation is that some immune function is involved in the development of D-galactosamine hepatitis since lymphocytes and macrophages, which release some cytotoxic cytokines such as tumor necrosis factor, were shown to preferentially consume glutamine especially when these cells were activated $(23,24)$. Further, proliferation of Kupffer cells in rat liver were observed after D-galactosamine injection (25). More detailed study is necessary to elucidate the mechanism by which gluten attenuates the elevation of serum transaminase activities caused by galactosamine.

These results demonstrated that the elevation of serum AST and ALT activities by D-galactosamine, a hepatotoxin, was promoted by a high-casein diet but was attenuated by a high-gluten diet. Such effects of gluten was not caused by a deficit of L-lysine and L-threonine but glutamine was not ruled out as a possible cause. The suppressive action of dietary gluten on the elevation of serum transaminases was not coordinated with the reduction of UTP and UDP-glucose after D-galactosamine injection.

The authors wish to thank Chiba Flour Milling Company (Chiba, Japan) for their partial financial support of the present study.

\section{REFERENCES}

1) Keppler, D., Lesch, R., Reutter, W., and Decker, K. (1968): Experimental hepatitis induced by D-galactosamine. Exp. Mol. Pathol., 9, 279-290.

2) Decker, K., and Keppler, D. (1974): Galactosamine hepatitis: key role of the nucleotide deficiency period in the pathogenesis of cell injury and cell death. Rev. Physiol. Biochem. Pharmacol., 71, 77-106.

3) Keppler, D., Pausch, J., and Decker, K. (1974): Selective uridine triphosphate deficiency induced by D-galactosamine in liver and reversed by pyridine nucleotide precursors. J. Biol. Chem., 249, 211-216.

4) Gross, V., Ludolph, D., Vom Berg, D., Kreisel, W., Andus, T., Katz, N., GiffhornKatz, S., Heinrich, P. C., and Gerok, W. (1990): Hepatocyte specific long lasting inhibition of protein $\mathrm{N}$-glycosylation by D-galactosamine. Biochim. Biophys. Acta, 1036, 143-150.

5) McDowell, W., Weckbecker, G., Keppler, D., and Schwarz, R. T. (1986): UDPglucosamine as a substrate for dolichyl monophosphate glucosamine synthesis. Biochem. J., 233, 749-754.

6) Kröger, H., Grätz, R., Museteanu, C., and Haase, J. (1981): The influence of nicotinamide, tryptophan and methionine upon galactosamine-induced effects in the liver. Arzneim.-Forsch./Drug Res., 31, 987-993.

7) Grün, M., Liehr, H., and Rasenack, V. (1976): Significance of endotoxaemia in experimental "galactosamine-hepatitis" in the rat. Acta Hepato.-Gastroenterol., 23, 64- 
81.

8) Iwaki, Y., Noguchi, K., Abe, H., Tanikawa, K., and Tsuda, K. (1988): Role of endotoxin in D-galactosamine induced hepatic injury. Kanzo, 29, 1043-1050.

9) Yamaguchi, M. (1980): Tanpakushitu aminosan ni tsuiteno eiyou jikken, in Syou Doubutsu wo Mochiiru Eiyou Jikkenn (in Japanese), ed. by Hosoya, N., Innami, S., and Goto, S., Daiichi Shuppan, Tokyo, pp. 127-152.

10) National Research Council (1985): Guide for the Care and Use of Laboratory Animals. NIH publication no. 85-23 (rev.), U.S. Government Printing Office, Washington, DC.

11) Keppler, D., Rudigier, J., and Decker, K. (1970): Enzymatic determination of uracil nucleotides in tissues. Anal. Biochem., 38, 105-114.

12) Hirotsu, T. (1992): Jikken Deta no Kaiseki (in Japanese), ed. by Hirotsu, T., Kyouritsu Shuppan, Tokyo, pp. 94-106.

13) Wilcox, P. E. (1967): Determination of amide residues by chemical methods, in Methods in Enzymology, Vol. 11 (Enzyme Structure), ed. by Colowick, S. P., and Kaplan, N. O., Academic Press, New York, pp. 63-77.

14) Häussinger, D., Lang, F., and Bauers, K. (1990): Interactions between glutamine metabolism and cell volume regulation. Eur. J. Biochem., 188, 689-695.

15) Hofman, F., Wilkening, J., Nowack, J., and Decker, K. (1976): Response of isolated rat hepatocytes to D-galactosamine and uridine. Hoppe-seyler's Z. Physiol. Chem., 375, 427-433.

16) Eisenmann, A., Phillips, J. E., Schulze-Specking, A., and Decker, K. (1984): On the mechanism of lactate dehydrogenase leakage from normal and D-galactosaminetreated hepatocytes in monolayer culture. Hoppe-Seyler's Z. Physiol. Chem., 365, 427436.

17) Nakamura, T., Fujii, T., and Ichihara, A. (1985): Enzyme leakage due to change of membrane permeability of primary cultured rat hepatocytes treated with various hepatotoxins and its prevention by glycyrrhizin. Cell Biol. Toxicol., 1, 285-295.

18) Galanos, C., Freudenberg, M. A., and Reuter, W. (1979): Galactosamine-induced sensitization to the lethal effects of endotoxin. Proc. Natl. Acad. Sci. U.S.A., 76, 59395943.

19) Windmueller, H. G., and Speath, A. E. (1974): Uptake and metabolism of plasma glutamine by small intestine. J. Biol. Chem., 249, 5070-5079.

20) Wilmore, D. W., Smith, R. J., O’Dwyer, S. T., Jacobs, D. O., Ziegler, T. R., and Wang, X. (1988): The gut: a central organ after surgical stress. Surgery, 104, 917-923.

21) Fox, A. D., Kripke, S. A., DePaula, J., Berman, J. M., Settle, R. G., and Rombeau, J. L. (1988): Effect of a glutamine-supplemented enteral diet on methotrexate-induced enterocolitis. J. Parenter. Enteral Nutr., 12, 325-331.

22) Souba, W. W., Roughneen, P. T., Goldwater, D. L., Williams, J. C., and Rowlands, B. J. (1987): Postoperative alterations in interorgan glutamine exchange in enterectomized dogs. J. Surg. Res., 42, 117-125.

23) Szondy, Z., and Newsholme, E. A. (1989): The effect of glutamine concentration on the activity of carbamoyl phosphate synthetase II and on the incorporation of ${ }^{3} \mathrm{H}$ thymidine into DNA in rat mesenteric lymphocytes stimulated by phytohemagglutinin. Biochem. J., 261, 979-983.

24) Souba, W. W. (1992): Glutamine and the immune system, in Glutamine, Physiology,

Vol. 42, No. 2, 1996 
Biochemistry and Nutrition in Critical Illness, ed. by Souba, W. W., R G Landes Company, Austin, pp. 41-46.

25) Lesch, R., Reutter, W., Keppler, D., and Decker, K. (1970): Liver restitution after acute galactosamine hepatitis: Autoradiographic and biochemical studies in rats. Exp. Mol. Pathol., 12, 58-69.

26) American Institute of Nutrition, (1977): Report of the American Institute of Nutrition ad hoc committee on standards for nutritional studies. J. Nutr., 107, 13401348. 